\title{
Socialism v. Democracy?
}

The IWMA in the USA, $1869-1876$

\author{
Michel Cordillot
}

The history of the International Working Men's Association (IWMA) - better known as the First International - in America was at once brief and original. Established in New York City in December 1869, it expanded rapidly to include some 4 ooo members and sixty language sections in twenty-five cities; four years later, it was almost extinct.

This history, often reduced to the minor role played by the Americans after the surprise decision of The Hague Congress to transfer the seat of the General Council to New York City in 1872 , prelude to an impending demise, remained largely ignored for the next century. However, the past fifty years have witnessed a renewal of interest. Following Samuel Bernstein's pioneering book (1962), Hubert Perrier explored new avenues of research in his thesis (1984). Other scholars followed suit, bringing up new questioning and broaching the often debated question of the "absence" of socialism in the USA from a different angle. The present paper is an attempt to suggest a new overall interpretation of the history of the IWMA in the USA and its historical legacy.

\section{First Footings in America}

Five years elapsed after the founding of the IWMA in London before it managed to establish a permanent foothold in the USA. After several fruitless attempts, Section 1 (German) was officially set up in early December 1869, Section 2 (French) in June 1870, Section 3 (Czech) a few weeks later, all of them in New York City. Although ties were established simultaneously with several American reform organizations, including the "New Democracy", the IWMA initially put down roots in various immigrant communities, eliciting a warning from the General Council worried that it might be perceived as a "foreign" organization. Things could have turned out differently, since the first national us labor organization, the National Labor Union (NLU), had contacted the IWMA on its own initiative in 1868. But despite the presence of a delegate at the Basel Congress (September 1869), the NLU never formally joined the IWMA, in part because of the untimely death of its founder William Sylvis. 
The conjunction of several dynamics made possible the success of this new attempt at the end of 1869. First, there was the international expansion of the IWMA at the time when it was rapidly gaining ground in Europe following the Basel Congress (September 1869) - an ominous fact discussed at length by the American press. Next, a complex and contradictory local context combining structural economic changes (rise of female labor, technological evolutions undermining the traditional structure of employment, mass immigration...), a fluctuating economic situation in the aftermath of the Civil War (with a spectacular industrial boom, but also a difficult transition from a war-time to a peace-time economy resulting in a first economic recession in $1866 / 67$, followed by a second one in $1869 / 71$ ), and rising social tensions (the offensive strikes wave in 1868/69, was followed by a series of defensive movements, then again by a vigorous demand for the eight-hour work day) even though the Us labor movement was still hesitant about its modes of organization (trade unions, international unions, city trades' assemblies, industrial congresses...) and its reform projects, as in the case of the National Labor Union. Last but not least, there existed a series of dynamics specific to each immigrant community. In August 1869, the founding in Eisenach of the SDAP, a social-democratic party challenging the Lassallean ADAV encouraged the mobilization of German political refugees, whereas the rapid deterioration of the political situation in France had already triggered the reactivation of the old political networks among the forty-eighter exiles, especially the former followers of Cabet, leading to the formation in 1868 of the Union républicaine de langue française. The harassment of the International leaders in France (May 1870), and the Franco-Prussian war (July 1870-January 1871) stimulated a process of further radicalization which led many to join the IWMA and adhere to a form of socialism conceived as the maximalization of the Republic.

All these dynamics, favorable at first, later took a downturn, causing a progressive decline in mobilization and eventually the near disapperance of most sections, until the decisive vote in July 1876 to officially dissolve the IWMA (at least the "centralist" one).

The first American Internationalists had to face an early test of will with the outbreak of the Franco-Prussian war. Immediately following the proclamation of the Republic in Paris on 4 September 1870 French and German members initiated hand-in-hand two mass meetings in New York City, with the support of several American organizations, to demand the end of military operations and peace without annexation. Still traumatized by the terrible conflict they had just come through, the Americans watched the evolution of the European situation closely, and these initiatives were again largely discussed in the press. As a result, several new sections of the IWMA were organized within weeks. 
It had become urgent to set up a structure which could coordinate the activities of sections in which different languages were spoken. In December 1870, the suggestion made by Eugène Dupont, who sat on the General Council in London, to form a "central committee" for North America was adopted and it soon became a de facto executive organ whose role was to stimulate the development of the nascent organization. Despite material difficulties related to a chronic shortage of funds, it managed to gain some visibility, especially after having demonstratively welcomed in the port of New York several Irish Fenians recently released from British jails (leading to the formation of three small Irish sections later on).

\section{The Paris Commune and America}

While the IWMA had been rescued from obscurity by the Franco-Prussian war, the Paris Commune brought it into the spotlight. Us public opinion was appalled. Except for a handful of native radicals, including the famous abolitionist leader Wendell Philipps, who announced publicly their support of the Parisians, the great majority of Americans reacted negatively to put it mildly. Conversely, the response of the Internationalists - the French first of all - and their sympathizers was enthusiastic. The membership of the IWMA soared, and the number of sections rose spectacularly from six in May 1871 to thirtyfive by the end of November (before reaching forty-five in the Spring of the following year). Important sums of money were also collected to help the vanquished who had managed to flee Paris.

The German sections (about twenty in number) were headed by politically well-trained refugees. They could rely on a migratory dynamic which provided them with a mass ethnic base. In New York City, German immigrants accounted for $22 \%$ of all industrial workers: in June 1869 , the Arbeiter Union included twenty-three German-speaking unions and had its own newspaper - which disappeared in September 1870 when rampant nationalism caused its circulation to collapse owing to its anti-war stance. German immigrants were also reputed for being rather receptive to progressive and radical ideas, and the German socialists dominated several organizations of skilled workers. It was no surprise that Germans represented about half the total membership of the IWMA in the USA.

The English-speaking sections (eighteen altogether) also developed spectacularly. As convincingly demonstrated by Timothy Messer-Kruse, they drew on the American reform tradition dating back from the revolutionary era and on the development of closer ties with the progressive wing of the labor 
movement in New York City. The IWMA banners could thus be seen floating over the speakers' platform erected for the eight-hour day demonstration on 13 September 1871 , which was attended by 20,000 New York workers despite a heavy downpour.

French immigration in the us was unquestionably of marginal importance. Yet, the dramatic sequence of events of the "Terrible year", followed by the arrival of a handful of communards who had escaped the "Bloody week" massacres, stirred up a strong emotional response among the local communities, leading to the multiplication of francophone sections ( $17 \mathrm{of} \mathrm{them).} \mathrm{The} \mathrm{French}$ Internationalists (together with the "autonomist sections") also initiated the impressive demonstration - the largest of its kind throughout the world which took place in New York City on 17 December 1871 to honor the Parisian Fédérés and their sacrifice (see Figure 17.1). On that day, thousands of demonstrators marched in Manhattan behind a banner inscribed "Honor to the martyrs of the universal Republic" and an ocean of red flags preceded a horsedrawn hearse flanked by an honor guard of exiles and ex-communards, as tens of thousands of rather well-meaning onlookers stood by. To the great dismay of the conservatives and the police, not a single incident was recorded.

Thanks to the electric telegraph, this event made front-page headlines in the Monday issue of many papers throughout the country (see illustration: Frank Leslie's, 6 January 1872).

\section{Feuds and Schisms}

This spectacular development of the IWMA was however somewhat deceptive. The coordinating efforts of the central committee were rapidly thwarted by internal strife. While all the sections shared such basic values as internationalism and, in theory at least, some long term goals (though a wide range of interpretations of such terms as "emancipation of workers" or "socialism" existed), essential divergences in terms of strategy soon became evident. In addition, the geographical dispersion of the various sections over a vast territory - among other factors specific to the USA - made coordinating actions difficult and tended to accentuate their isolation.

In early December 1871, after several weeks of latent conflict, the central comittee split into two rival federal councils. The general context was grim: the communards had been defeated, and back in Europe, the unity of the IWMA was clearly threatened after the London conference of September 1871 had voted measures deemed unacceptable by Bakunin and his allies, and more generally by all those who favored federalism. Ironically, the split in America 
took place at the very moment when the IWMA had scored its first popular success with the mass demonstration of 17 December 1871.

Things were simple in appearance. The so-called "centralist" (or Tenth ward hotel) faction, which consisted mostly of german-speaking members claiming to be loyal to Marx, saw itself as the gatekeeper of socialist orthodoxy. Its aim was to counter the bid for leadership of the so-called "autonomist" (or Spring Street) faction led by American Sections 12 and 9, regarded as perverted by petty bourgeois idelogy, or worse. The French sections (by then accounting for about one third of the IWMA membership) were caught in the crossfire.

Yet, as Perrier demonstrated, the reality was more complex. Despite their professed loyalty to Marx and their exclusive commitment to the working class, the centralists' positions were not devoid of ambiguities. Their American experience and the evolution of the National Labor Union had made them cautious, and they gave absolute priority to trade-union activity, refusing obstinately any form of political or electoral activity "in the present state", contrary to what had been advocated by resolutions voted in London (at Marx's instigation). The American autonomists (who unlike Bakunin were not intent on refusing political action or destroying the state, demanding rather its ultimate democratization,) favored the creation of a political party - as voted in London. They would welcome all types of radicals (not just workers) in order to promote various reforms in favor of the working classes, as well as women, Negroes, cooperatives and so on. They planned to amend the American Constitution and publicize their views during the upcoming presidential campaign by running a ticket associating an ineligible woman (Victoria Woodhull) and a former slave (Frederick Douglass).

The forceful irruption of the English-speaking sections had in fact raised the question of the Americanization of socialism. The real issue was whether the theoretical schemes imported from Europe could be applied unchanged on the other side of the Atlantic, or whether it was advisable to draft a program taking fully into account the national democratic tradition so as to foster an extension of native radicalism.

Dissensions crystalised around Section 12 and its most provocative proposals, including its demand to be recognized by the General Council as the "leading section" in the USA. Yet it appears that after the split, the main inspirator of the autonomist Spring Street council almost immediately ceased to be Section 12, many members of which rapidly lost interest in the factional strife of the International, and became Section 9, which stood its ground and continued to propose, from within, an electoral and unionist strategy coherent with American traditions, with the entry of workers in the political arena its central priority. 
Because the two rival American factions defined themselves using the same terms as the two European factions (centralists v. autonomists), they actually confused the issue by creating the impression that their disagreements were merely the American rendition of the European feud. It is obvious that to justify their ideological stubbornness the centralists deliberately pretended to position themselves in the conflict between Marx and Bakunin, whereas the two disputes were compeletely distinct.

To these political disagreements, which also corresponded largely to an ethnic confrontation (German-speaking immigrants v. English-speaking members), must be added the pussyfooting of the French sections, almost exclusively preoccupied with helping the communard refugees. The landing in New York of nearly 200 of the latter, often with their families, in the Fall of 1871 had enabled the Blanquists to secure the defacto leadership of the French-speaking sections and the editorial control of their national newspaper, Le Socialiste, making the situation even more confused. In the London General Council, the Blanquists were Marx's most loyal allies, and this situation remained unchanged until The Hague Congress in 1872. But in New York City, the self-professed Marxists refused to accept what the Blanquists regarded as essential, i.e. the creation of a revolutionary political party, whereas their autonomist adversaries regarded this as their priority. Hence the relative neutrality of the French sections in the American conflict between December 1871 and September 1872.

The London General Coucil postponed its own decision for several months. When it finally decided in May 1872 to arbitrate in favor of the centralists and to suspend Section 12 pending the decision of the general congress due to take place in September, the gap between the warring factions had become unbridgeable. While the centralists rigidly concentrated on their trade-union activities, the autonomists were uncertain. Section 12 was busy building a large political coalition in which various reform movements, including the feminists, the money reformers, and the Spiritualists, would have their place. Very active in the unemployed movement, the members of Section 9 - which was mostly working-class in composition despite the centralists' allegations - took the initiative to organize an important demonstration in New York City on 14 March 1872 , and by doing so directly challenged Section 1 on its own turf. Their goal was avowedly to launch a local labor party formulating concrete demands. But following their complete failure to convince the delegates at the founding congress of the Labor Reform Party held in Columbus (Ohio) in February 1872 to adopt their platform, as a last resort they decided to rally to the candidacy of Victoria Woodhull and take part in the foundation of the Equal Rights Party (11-12 May at the Apollo Convention Hall in New York City). Much of their credibility was lost in the ensuing debacle. 
Next, in July, two rival American congresses were held to prepare the general congress at The Hague: twenty-two sections, including two French sections, were represented at the centralist one while 13 sections, including two French sections, attended the autonomist congress. About 10 French sections had decided to stay away from both congresses. At the same time that new sections were being formed, the existing ones had started to lose members rapidly.

\section{The Hague Congress and Its Consequences}

Among the important decisions voted at The Hague (September 1872) was the transfer of the seat of the General Council to New York City. Regardless of its real motivations, this decision was an ill-fated one. In the USA, the internicine war was still raging. The labor movement had lost its momentum after the setback suffered by the eight-hour movement - of the 100 ooo workers who had struck in New York City, only one in eight had had done so successfully - and, frightened by the intense press campaign, an increasing number of unions were now trying to distance themselves from the "communists". The hard core of the New York socialist movement had shrunk to a handful of german-speaking unions relatively insulated by the language barrier, such as the cigar makers union, soon to become under the leadership of Internationalists like Gompers, Laurrel and Strasser, a social laboratory promoting a socialist inspired version of trade-unionism.

Feeling to some extent legitimized - and encouraged in their complex of doctrinal superiority - by the decision voted at The Hague, the centralists gave the impression they had found a new lease of life for some time, whereas the Spring Street faction, initially more dynamic, was rapidly losing ground. As for the French blanquists, now "internationalists without the International" after their break with Marx at The Hague, they isolated themselves in an increasingly more sterile bravado which progressively exacerbated the fault-line between the old forty-eighters who had chosen to build a new life in the USA and the communard refugees eager to go back home as soon as possible. The final break was to occur in 1875, when the old Bulletin de l'Union républicaine resurfaced to replace Le Socialiste. Henceforward, only the periodic fund-raising drives to alleviate the fate of the Parisian insurgents transported to New Caledonia could temporarily reconcile all the French exiles.

In the fall of 1873, the failure of Jay Cooke \& Company signaled a nationwide economic debacle, soon to have repercussions in other industrialised countries. Within weeks, the number of unemployed rose to 100,000 in New York City alone. The internationalists mustered their last forces. Building on their German-speaking strongholds, the centralists tried to organize the foreign 
unemployed. Whatever autonomists were still active did the same among English-speaking workers. Quite successfully so, since by mid-December, 23 organizations numbering some 10 ooo people out of work voted for the creation of a Committee of Public Safety - an obvious tribute to the communards - which called a demonstration in Tompkins Square on 13 January 1874. Worried about the extension of the movement to Chicago, Saint Louis, Cincinnati, Boston, Newark and other cities, the local authorities reacted violently. Several thousand demonstrators were brutally dispersed by the police, and the repression that followed caused the complete collapse of the unemployed movement.

\section{The Demise of the International}

After this setback, the American IWMA was the shadow of its former self. The last autonomists fell back on their respective unions. The Blanquists, who had attended the demonstration in full force, returned to an even greater isolation, whereas the German sections were about to face an internal crisis echoing the one already tearing up the Austrian social-democracy.

The final act took place on 15 July at the Philadelphia conference organised during the Centenial Exposition, when ten delegates representing thirteen German sections and 635 members in good standing voted the final dissolution of the IWMA. The founding congress of the Workingmen's Party of the United States, the first American socialist party claiming at once 3,000 members, was to open in the same hall four days later (19-22 July).

The IWMA was thus obviously short-lived in the USA. Born quite late, a few months hence it saw the progressive inversion of the social, political, and migratory dynamics which had stimulated its rise. The International was by then divided and persecuted in Europe. The 1873 crisis had strongly curtailed the economic boom of the post-Civil War years, and the union mobilization was ebbing. The Franco-Prussian war and the tragical outcome of the Paris Commune had plunged the socialists into disarray. This downturn began during the second half of 1871 , yet it remained unperceived for some time because of the creation of new sections throughout 1872 . Precipitated by the split of December 1871, the decline of the IWMA in the USA had nonetheless become irreversible.

\section{The Legacy of the International in America}

Today the American history of the IWMA is all in all well established. The main question remains to assess the legacy of this experience. What was its impact 
on organized labor, on the socialist movemement, and more generally on American public opinion?

It is not necessary here to dwell at length on the first two points, already thoroughly explored by Perrier and Messer-Kruse. Indeed they (and others) have shown that despite the disillusionment resulting from this failed attempt, some of the ideas promoted by the autonomists continued to make their way within the great reform movement of the Knights of Labor ( $\mathrm{K}$ of L). Also, some prominent representatives of the Spring Street faction played an oustanding role in formulating the syndicalist and revolutionary tenets of the International Working People's Association (IWPA) in the 1880s. Suffice it to say that the French activist Victor Drury was co-author of the Pittsburgh Manifesto of the IWPA (1883) and at the same time a member of the progressive DA 49 of the $\mathrm{K}$ of $\mathrm{L}$ and of the mysterious but powerful Home Club. In the same vein, Perrier and Messer-Kruse have also convincingly shown how some former centralists - notably Samuel Gompers - gradually moved from progressive unionism towards a pansyndicalist credo, eventually to become apostles of the "pure and simple unionism" of the American Federation of Labor.

Lastly, their contribution remains essential to understand the place of the IWMA in the history of the American Left, since it was the first of a series of organizations advocating socialism and later communism (WPUS, SLP, SPA, CPUSA). What needs be stressed here is that the internal squabbles and the exclusion of the autonomist faction prevented the emergence of a genuinely American brand of socialism, and that the decades following the demise of the IWMA were, as a result, characterised by a nearly complete hegemony of "German" socialism in the USA, thus tending to validate the idea that socialism was indeed a "foreign" ideology.

Still debated is the important question of the impact of the IWMA on American public opinion. Here it is necessary to adopt a wider angle and take a brief look back. During the first half of the 19th Century, the revolutionary origins of the nation and its conquests, including the franchise, generally remained a source of pride for many Americans still influenced by their Jeffersonian heritage. Sharing an egalitarian political culture supposed to transcend partisan divisions, they did not hesitate to support those who fought against despostism and absolutism elsewhere in the world. Because they saw themselves as pioneers in the struggle against tyranny, Americans regarded foreign revolutionaries as brothers in arms, to the great displeasure of European absolutist governments. This was obvious enough in 1848 when the revolutionary uprisings of the "Spring of Nations" were almost unanimously welcomed in America.

Yet this unanimity did not last. After the Paris insurrection of June 1848, the spectre of communism also began to haunt America. Due to the absence of restrictive laws concerning immigration, thousands of defeated European 
démoc-socs migrated to the United States in the early 1850 , but by then their ideas were already perceived as too extremist.

A complete change of perspective prevailed in the course of the three following decades. For American public opinion, the notion of Revolution ceased to be identified with democratic progress and became synonymous with social disorder. Confronted with the upheaval of Reconstruction after a bloody Civil War, the American Nation was by then afraid of possible social (and racial) subversion. Such an unstable climate did much to prepare American public opinion to internalize an in-depth transformation of the republican ideological legacy based on a Darwinian approach to us society. As spectacular economic progress galvanized the mystique of individual success, more and more voices rose to condemn all forms of egalitarianism and socialism.

The turning point must be looked for somewhere between 1871 and $1877 .^{1}$ Because it was perceived as a warning of the impending threat represented by the laboring classes to property and order, and possibly to the Republic itself, the Paris Commune paved the way for this inversion of values in the collective thinking of Americans. The demonstrations held under the aegis of the IWMA plus the well publicized arrival in the us of a few hundred communard refugees did little to restore peace, and the spirit of conservatism definitely superseded the spirit of progress when the near insurrectional railway strikes erupted in 1877. For the great majority of Americans, whether large, small, or would-be proprietors, Revolution had ceased to be identified with the legitimate struggle of oppressed people for greater freedom, and took on the hideous appearance of a menace against property and the gospel of personal success. Now instinctively conservative, the great majority of Americans were ready to join the crusade against social subversion. Confronted with ever more violent social movements (in $1886,1892,1893 \ldots$ ), and having to cope with the challenge of mass immigration, Americans started to worry about their cultural identity, convinced that a new plot was being hatched against them, this time by "Reds" willing to promote unamerican theories imported from Europe. The radicalization of the small socialist groups, their de facto "germanification", their revolutionary and sometimes militaristic rhetoric, and their rejection of any kind of alliance with native reformers, contributed to the painting of socialism as an ideology bent on forcefully imposing a State controlled economy, which was unacceptable for most American citizens.

The rapid rise of the IWMA and its incredible press coverage briefly gave the impression that socialism might acquire a lasting influence in the USA.

1 For a more complete discussion of this problem, see Michel Cordillot, « Socialisme et démocratie aux États-Unis : des idéaux politiques incompatbles? », in Jean Vigreux et Serge Wolikow (eds), Rouge et rose. Deux siècles de socialismes européens (Dijon, 2007), pp. 189-206. 
However, the events of the Commune, and perhaps even more so the internicine quarrels which resulted in marginalization of the American sections advocating a large alliance of all reformers by the German "Marxist" sections, were instrumental in quashing all hopes of significant progress.

In the mid-188os, America lived through another bout of social fever. But the dramatic events in Chicago (4 May 1886) in the wake of the eight-hour movement and their tragic epilogue with the hanging of the anarchist communist leaders on 11 November 1887 showed that the powers that be would not hesitate to use force. Though not directly involved, many socialist and labor organizations were affected collaterally by the shock wave. Many tradeunion leaders were left with the conviction that in order to survive, labor organizations would have to give up trying to transform the existing social order. Compelled to accept the system based on free enterprise, they encouraged union workers to stick to bread and butter issues. In the decades following Haymarket, the revolutionary Left did not altogether disappear. Though vocal and sometimes heeded, it was however confined to a minority status in the American labor movement. For an exasperated public opinion, socialism (and later communism) would henceforward be identified with ideas stirred up by foreign agitators, and accordingly incompatible with the values inherited from the Founding Fathers. Electorally marginalized, the "Reds" were pushed to the external fringe of the national community.

This evolution was mostly the result of specific historical circumstances rather than the direct consequence of what the IwMA had done - or had failed to do. Nonetheless, the organization had played its part in the process. So, in the end, it is also in its symbolic (and negative) dimension that the enduring legacy of the First International in America is to be found.

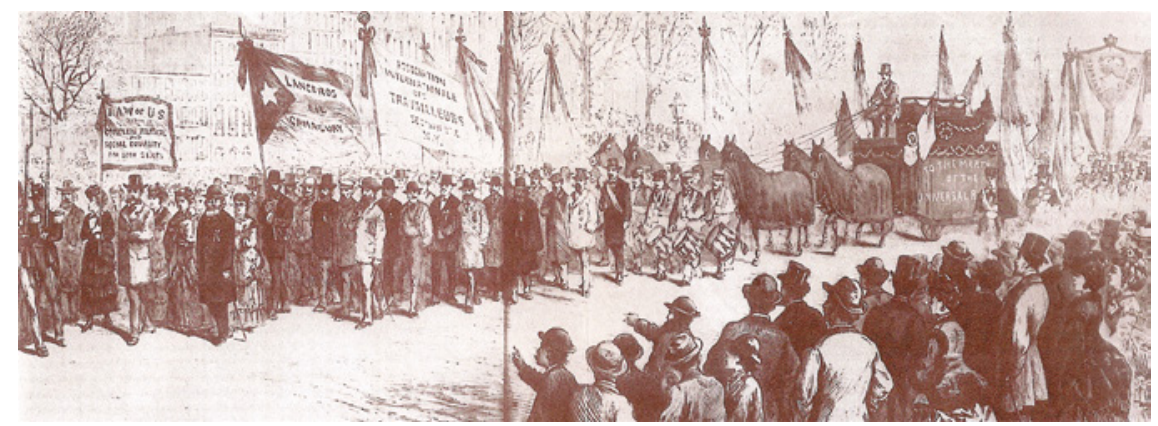

FIGURE 17.1

March of the French Internationalists in New York on 17 December 1871 to honor the Parisian Fédérés.

SOURCE: FRANK LESLIE'S, 6 JANUARY 1872. 


\section{Selected Bibliography}

\section{Firsthand Accounts}

Foner, Philip S.; Brewster Chamberlin eds., Friedrich A. Sorge's Labor Movement in the United States. A History of the American Working Class from Colonial Times to 1890, Wesport, Greenwood Press, 1977.

Gompers, Samuel. Seventy Years of Life and Labor, New York, Dutton, 1925.

Schlüter, Hermann. Die Internationale in Amerika. Chicago, Herausgegeben von der Deutschen Sprachgruppe der Sozialistischen Partei der Vereinigten Staaten, 1918.

\section{Secondhand Sources}

Bernstein, Samuel. The First International in America, New York, Kelley, 1962.

Cordillot, Michel. Utopistes et exilés du Nouveau Monde. Des Français aux États-Unis, de 1848 à la Commune, Paris, Vendémiaire, 2013.

Cordillot, Michel. La Sociale en Amérique. Dictionnaire biographique du mouvement social francophone aux États-Unis, 1848-1922, Paris, L'Atelier, 2002.

Messer-Kruse, Timothy. The Yankee International. Marxism and the American Reform Tradition, 1848-1876, Chapel Hill, The University of North Carolina Press, 1998.

Steven Parfitt. « Brotherhood From a Distance: Americanization and the Internationalism of the Knights of Labor », International Review of Social History 58 (2013) pp. 463-491.

Perrier, Hubert. Idées et mouvement socialiste aux États-Unis, 1864-189o, Thèse d'État, Université Paris VIII, 1984.

Perrier, Hubert. «De l'internationalisme au syndicalisme "pur et simple". L'influence de l'AIT sur le mouvement ouvrier américain », Cahiers d'histoire de l'IRM, ${ }^{\circ} 37$ (1989), pp. 107-123.

Perrier, Hubert. « Radicalisme américain et socialisme : les sections "autonomistes" de la Première Internationale aux États-Unis », in Jean Heffer et Jeanine Rovet (dir.), Why is There no Socialism in the Us? Pourquoi n'y a-t-il pas de socialisme aux ÉtatsUnis ?, Paris, E HEss, 1987, pp. 193-207. 